\title{
Perkembangan Morfo-anatomi Bunga, Buah, dan Biji Nyamplung (Calophyllum inophyllum L), Sebagai Tanaman Penghasil Biodisel
}

\author{
Morpho-Anatomy Development of Flower, Fruit and Seed of \\ Nyamplung (Calophyllum inophyllum L) as Biodiesel-Producing \\ Plant
}

HAMIM", ZAHRUL ROMADLON, DORLY

Departemen Biologi, Fakultas MIPA, Institut Pertanian Bogor, Kampus IPB Dramaga, Bogor 16680

Diterima 6 Februari 2019/Disetujui 27 Mei 2019

\begin{abstract}
Nyamplung (Calophyllum inophyllum), a non-edible producing plant, is a tropical plant traditionally used by local residents as firewood, building material and medicinal plants. The research aimed to study the development of flower and fruit as well as oil content of nyamplung seeds. Two adult trees (P1 and P2) with different provenance were used in experiment. Morphology of flower and fruit, and seed germination were observed from the field, while the microscopic anatomical observations and oil content analysis were carried out in the laboratory. The result showed that a single generative bud generally had 8-15 flowers. The flower was arranged in bunches, with 4 petals, 4 sepals, single pistil and 4 files of anthers surrounded the pistil. In some cases, the flowers had 5 sepals, or 3 sepals and 3 anthers files. Fruits were round, green and turned to harden with brownish color during maturation. Flower bud grown from bud was ready to blossom 27 days after initiation (DAI). There were up to $48.52 \%$ flower buds drop at 24 DAI, and they were still increase up to $64.5 \%$ flower drop during the whole of flower development. The observation also showed that fruit drop rate of P2 plant was higher than P1. After flower bloom for 3 or 4 days after anthesis, the flowers started to lose their parts. The fruits started to ripe 8-10 week after anthesis (WAA). Seeds from P2 tree had oil content of $51.79 \%$, which was higher than the P1 tree $(42.57 \%)$.
\end{abstract}

Key words: Lemak, anthesis, kerontokan buah, absisi

\section{PENDAHULUAN}

Nyamplung (Calophyllum inophyllum L.) adalah tanaman tropis yang biasanya tumbuh di daerah dataran rendah dan pesisir, meskipun terkadang juga dapat ditemukan di dataran tinggi (Friday dan Okano 2006). Tanaman ini tersebar di wilayah tropis Asia sepanjang Melanesia hingga Polinesia (Dweck dan Meadow 2002). Nyamplung dikategorikan sebagai tanaman tingkat menengah dengan ketinggian bisa mencapai $2.5-5 \mathrm{~m}$, memiliki getah berwarna kekuningan yang jelas, dengan kulit luar kasar bersisik (Orwa et al. 2009).

Di Indonesia dan banyak negara Asia, nyamplung banyak digunakan terutama untuk medis, industri kayu termasuk industri kapal, dan beberapa penggunaan tradisional seperti kerajinan tangan yang dibuat dari biji nyamplung oleh masyarakat sekitar

*Penulis korespondensi:

E-mail: hamimhar@gmail.com
(Dweck dan Meadows 2002; Adinugraha et al. 2012). Minyak yang diekstrak dari biji nyamplung telah dikenal mampu menyembuhkan beberapa penyakit serta untuk digunakan sebagai bagian dari bahan kosmetik (Dweck dan Meadows 2002). Manfaat medis dari C.inophyllum juga karena kandungan asam canophyllic dan protein calophilin, yang salah satunya mampu menghambat penyebaran virus HIV (Dweck and Meadows 2002). Di Bali, nyamplung umumnya digunakan oleh masyarakat sekitar sebagai obat dan memiliki prospek komersial (Heyne 1987). Secara tradisional, kulit eksternal juga dapat digunakan untuk mengobati pembengkakan kelenjar sementara kulit internal dapat digunakan untuk obat diuretik (Rahayu 2009).

Selama dekade terakhir telah diketahui bahwa minyak nyamplung dapat digunakan sebagai bahan baku alternatif untuk biodiesel (P3HH 2008; Leksono et al. 2014). Biji Nyamplung memiliki kandungan minyak yang tinggi yang dapat digunakan sebagai bahan baku biofuel (Hamim dan Miftahudin 
2008; Fiani 2015). Kandungan minyak biji dapat menghasilkan asam lemak yang sesuai dengan standar persyaratan biodiesel (Azam et al. 2005). Seperti diketahui bahwa penurunan sumber bahan bakar fosil membuat pencarian sumber energi alternatif semakin intensif (Azam et al. 2005). Selain hasil produksi minyak yang tinggi, minyak nyamplung juga dikategorikan sebagai produk yang tidak dapat dimakan, dan budidaya tanaman nyamplung juga sangat sederhana (Putri dan Gheewala 2015) sehingga dalam perspektif ketahanan pangan, budidaya tanaman ini khususnya di lahan yang tidak subur tidak akan mengganggu produksi makanan pokok. Tetapi masih ada sedikit studi mengenai pembungaan dan pengembangan buah dan biji, oleh karena itu tanaman ini masih perlu dipelajari lebih lanjut (Dweck dan Meadows 2002). Penelitian ini bertujuan untuk mempelajari tahap pengembangan bunga, buah, dan biji nyamplung yang dapat digunakan untuk memprediksi kemampuan produksi.

\section{BAHAN DAN METODE}

Waktu dan Tempat. Penelitian ini dilaksanakan pada bulan Januari sampai Juni 2009 di Kecamatan Kragan Kab. Rembang, Laboratorium Anatomi dan Morfologi, Departemen Biologi FMIPA-IPB dan Laboratorium Uji Hayati, Universitas Brawijaya.

Alat dan Bahan. Penelitian ini menggunakan dua buah pohon sebagai objek pengamatan (Gambar 1). Kedua pohon masih dalam satu lokasi yang sama namun memiliki variasi pada warna bakal buah. Bahan-bahan yang digunakan untuk analisis kadar lemak diantaranya: pelarut heksan, asam sulfat pekat, asam borat $4 \%$, indikator conway, dan campuran selen. Sedangkan untuk pembuatan sediaan mikroskopis menggunakan parafin, pewarna Safranin, dan Fastgreen.

Alat-alat yang digunakan dalam pengamatan lapang diantaranya: mistar ukur, jangka sorong, kamera digital, dan alat tulis. Sedangkan untuk analisis lemak menggunakan alat soklet dan kromatografi gas. Untuk pembuatan sediaan mikroskopis menggunakan mikrotom putar dan oven.
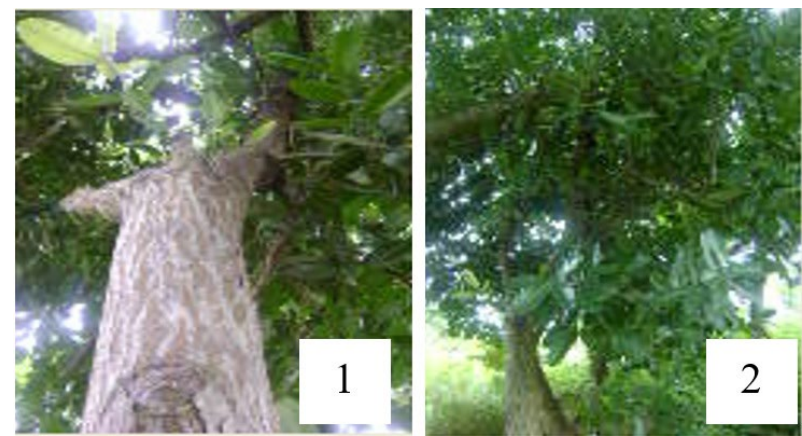

Gambar 1. Pohon objek pengamatan (1) P1 dan (2) P2
Pengamatan Perkembangan Bunga. Perkembangan bunga dari kuncup hingga mekar diamati struktur anatomi dan morfologinya. Pada masing-masing pohon, kanopi pohon dibagi dua posisi yaitu kanopi utara dan selatan.

Pengamatan terhadap kuncup bunga dimulai dari tunas muncul berupa tonjolan pada ketiak daun hingga tunas dewasa berupa tandan. Dilakukan pemilihan secara acak terhadap tunas yang akan di amati pada masing-masing posisi. Sebanyak 80 tunas sebagai ulangan pada masing-masing pohon. Pengamatan dilakukan secara periodik empat hari sekali. Setiap pengamatan dilakukan pencatatan terhadap panjang tunas, jumlah kuncup yang rontok, tipe tandan dan perubahan warna tunas, dan kuncup. Kuncup yang rontok dan bunga yang gugur dicatat untuk dikalkulasi dalam tingkat kerontokan kuncup dan bunga. Dilakukan pengamatan terhadap stadiastadia perkembangan bunga yaitu waktu anthesis, lama anthesis, bagian-bagian bunga yang gugur, dan kapan bunga gugur secara keseluruhan.

\section{Pengamatan Perkembangan Buah.} Perkembangan buah muda hingga buah matang diamati struktur anatomi dan morfologinya. Pengamatan dilakukan seminggu sekali dengan mengamati diameter buah (longitudinal dan transversal), perubahan warna kulit buah dan kerontokan buah. Sebanyak 100 buah sebagai ulangan untuk setiap pohon. Diameter longitudinal dan transversal buah diamati dengan jangka sorong secara periodik hingga panen. Setiap diameter yang diukur diambil dari dua sisi yang berbeda namun tidak pada sisi yang saling berlawanan (Gambar 2), data diameter di dapat dari rata-rata dua sisi tersebut. Pengukuran dilakukan dengan hati-hati agar tidak merusak kulit buah. Selain itu juga dilakukan pengamatan secara acak terhadap jumlah rata-rata buah. Pengamatan ini dilakukan ketika buah berumur 6 minggu setelah anthesis (MSA). Untuk pengamatan pertumbuhan buah dilakukan penyayatan buah pada beberapa periode perkembangannya. Di akhir pengamatan, buah akan dipetik untuk diukur bobot basah.

Pembuatan Sediaan Mikroskopis. Sediaan irisan melintang dan membujur kuncup bunga dan buah dibuat dengan metode parafin (Johansen 1940). Sampel berupa kuncup bunga (usia 4-20 hari setelah tunas) dan buah berbagai stadia (usia 1-7 MSA). Setiap sampel difiksasi di dalam larutan FAA $(5 \mathrm{ml}$ formalin, $5 \mathrm{ml}$ asam asetat glasial, $90 \mathrm{ml}$ alkohol $70 \%$ ). Selanjutnya dilakukan dehidrasi, penjernihan, dan infiltrasi.

Sampel yang telah difiksasi di dalam larutan FAA dicuci dengan alkohol 50\% sebanyak 4 kali masing-masing selama 1 jam. Proses dehidrasi dan 


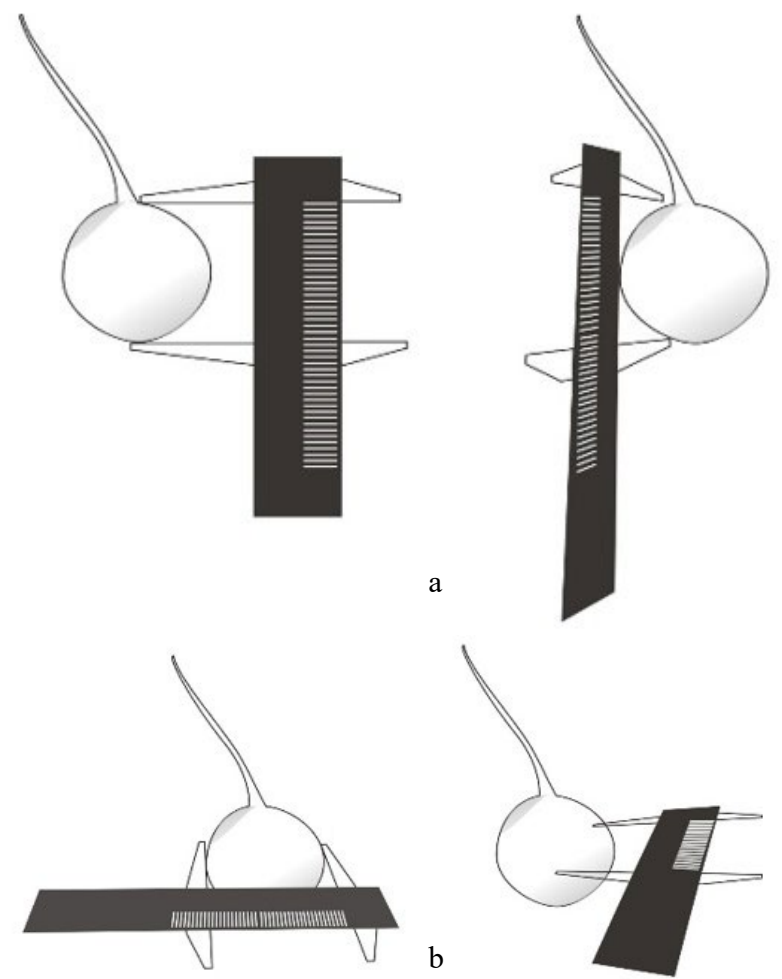

Gambar 2. Pengukuran diameter buah dengan jangka sorong, (a) diameter longitudinal, (b) diameter transversal

penjernihan dilakukan dengan merendam sampel di dalam larutan seri Johansen. Infiltrasi parafin ke dalam jaringan dilakukan secara bertahap dengan menambahkan parafin beku ke dalam wadah yang berisi sampel, tertier butyl alkohol, dan minyak parafin, kemudian dibiarkan terbuka pada suhu ruang selama 1-4 jam dan dilanjutkan di dalam oven suhu $60^{\circ} \mathrm{C}$. Setelah melalui infiltrasi jaringan ditanam di dalam blok parafin. Selanjutnya blok dilunakkan dengan merendam di dalam larutan Gifford selama 1 minggu. Kemudian sampel diiris setebal $10 \mu \mathrm{m}$ dengan menggunakan mikrotom putar. Pita parafin yang diperoleh direkatkan pada gelas objek di atas hotplate dengan suhu $40^{\circ} \mathrm{C}$ selama 3-5 jam. Selanjutnya dilakukan pewarnaan dengan safranin $2 \%$ dan fastgreen $0.5 \%$. Preparat yang telah diwarnai ditetesi entelan kemudian ditutup dengan gelas penutup dan diamati di bawah mikroskop.

Pengamatan Perkecambahan Biji. Biji diambil dari buah yang telah masak dan tua (jatuh). Sebanyak 30 kantong polybag yang telah berisi tanah dipersiapkan, 15 polybag digunakan untuk menguji perkecambahan biji P1, dan 15 sisanya untuk P2. Kemudian tiga biji dari masing-masing pohon ditanam di dalam setiap polybag. Media yang digunakan adalah tanah pasir agar sesuai dengan kondisi asli tanaman. Setelah biji berkecambah dilakukan seleksi di setiap polybag dengan mempertahankan kecambah yang lebih sehat dan terbaik, sehingga hanya tersisa satu kecambah di setiap polybag. Pengamatan dilakukan mingguan untuk mengamati persentase tumbuh kecambah, tinggi kecambah, dan jumlah daun.

Uji Kadar Lemak Biji. Pengujian kadar lemak dilakukan di Laboratorium Uji Hayati, Universitas Brawijaya. Pengujian kadar lemak dengan soklet menggunakan pelarut heksan mengikuti Danuwarsa (2006). Sampel ditimbang $3 \mathrm{~g}$ lalu dimasukkan ke thimble. Labu lemak yang telah bersih dimasukkan ke dalam oven, lalu ditambahkan batu didih, dan ditimbang sebagai bobot kosong. Thimble dimasukkan ke dalam soklet, kemudian labu lemak dihubungkan dengan soklet, dan ditambahkan pelarut heksan $150 \mathrm{ml}$ melewati soklet. Labu lemak dan soklet dihubungkan dengan penangas dan diekstrak selama 6 jam. Setelah ekstraksi selesai, labu lemak dievaporasi untuk menghilangkan pelarut. Selanjutnya labu lemak dimasukkan ke dalam oven 1 suhu $105^{\circ} \mathrm{C}$ selama $1 \mathrm{jam}$. Setelah dingin ditimbang sebagai bobot akhir (bobot labu dan lemak).

Penghitungan kadar lemak menggunakan rumus berikut:

Kadar lemak $=\frac{c-b}{a} \times 100 \%$

Keterangan:

$\mathrm{a}=$ bobot contoh

$\mathrm{b}=$ bobot labu lemak dan labu didih

$\mathrm{c}=$ bobot labu lemak, batu didih dan lemak

\section{HASIL}

Pertumbuhan dan Perkembangan Bunga. Munculnya tunas bunga ditandai dengan tonjolan berwarna kecoklatan pada ketiak daun. Seiring bertambahnya waktu, tonjolan tersebut tumbuh memanjang dan bulatan-bulatan sebagai bakal kuncup semakin terlihat jelas.

Berdasarkan grafik pertumbuhan panjang tunas (Gambar 3 dan 4) diketahui bahwa lama pertumbuhan dari tunas dari kecil hingga memiliki beberapa kuncup dewasa mencapai 27 hari setelah inisiasi(HSI). Namun ada tunas bunga yang memiliki kuncup dewasa pada 25 HSI dan 28-30 HSI. Tunas yang telah dewasa memiliki 8-15 kuncup bunga dengan panjang tangkai masing-masing kuncup $10-15 \mathrm{~cm}$.

Berdasarkan jumlah kuncup dan tata letaknya, $C$. inophyllum tergolong bunga majemuk yang tersusun secara tandan. Masing-masing tandan memiliki 8-15 buah kuncup. Jika dilihat dari ibu tangkai tandan dengan kuncupnya, bunga $C$. inophyllum $\mathrm{L}$. bertipe anak payung menggarpu majemuk (Gambar 5).

Berdasarkan sayatan membujur kuncup usia 7-8 HSI (Gambar 6.1), kepala putik, tangkai putik, dan bakal buah telah tampak jelas, namun kepala sari tampak belum matang. Pada gambar sayatan membujur 


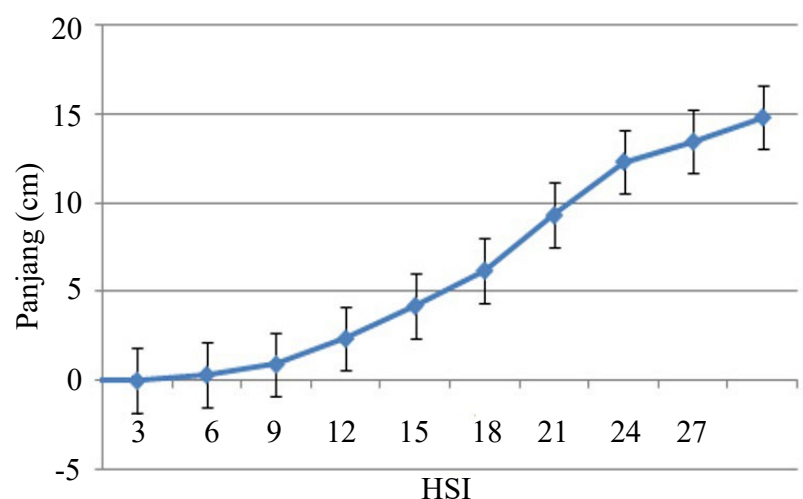

Gambar 3. Pertumbuhan panjang tunas bunga P1

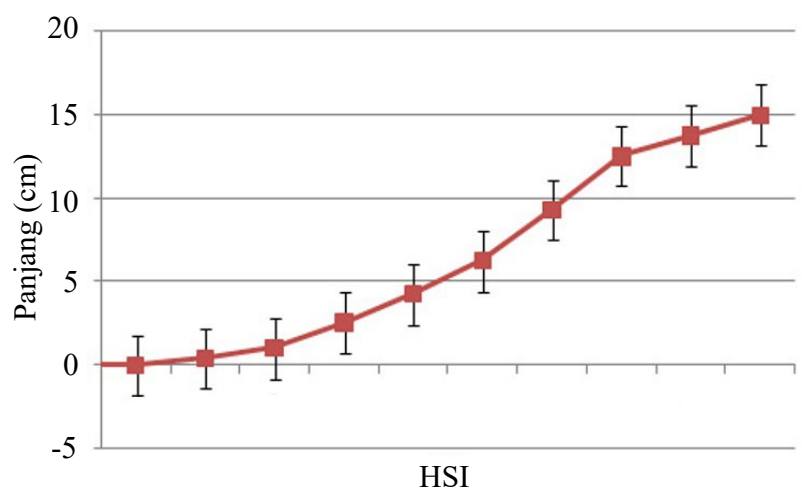

Gambar 4. Pertumbuhan panjang tunas bunga P2

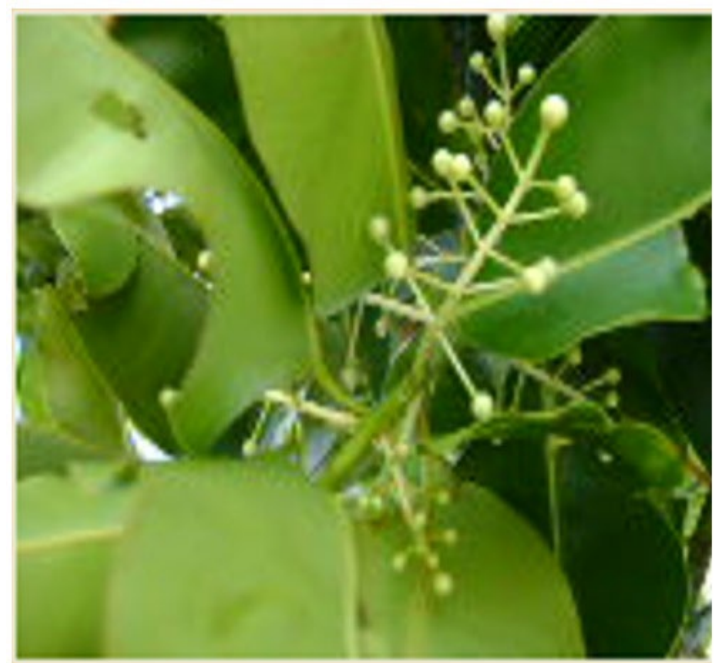

Gambar 5. Susunan kuncup bunga pada tandan

kuncup usia 15-16 HSI tampak kepala sari telah matang (Gambar 6.2). Bakal buah pada kuncup usia 21-22 HSI (Gambar 6.3) semakin berkembang dengan terdapatnya kantung lembaga di bagian tengah bakal buah.

Kuncup yang telah dewasa di tandai dengan warna putih pada kelopak dan memiliki tangkai kuncup dengan panjang 10-15 cm dengan permukaan kuncup yang tidak rata berupa tonjolan. Tonjolan tersebut nantinya menjadi kelopak bunga ketika anthesis. Tanda lainnya yang dapat diamati berupa kepala putik yang keluar di ujung kuncup bunga. Sedangkan kuncup yang masih muda memiliki warna kelopak hijau kekuningan dan permukaan kuncup tidak terdapat tonjolan.
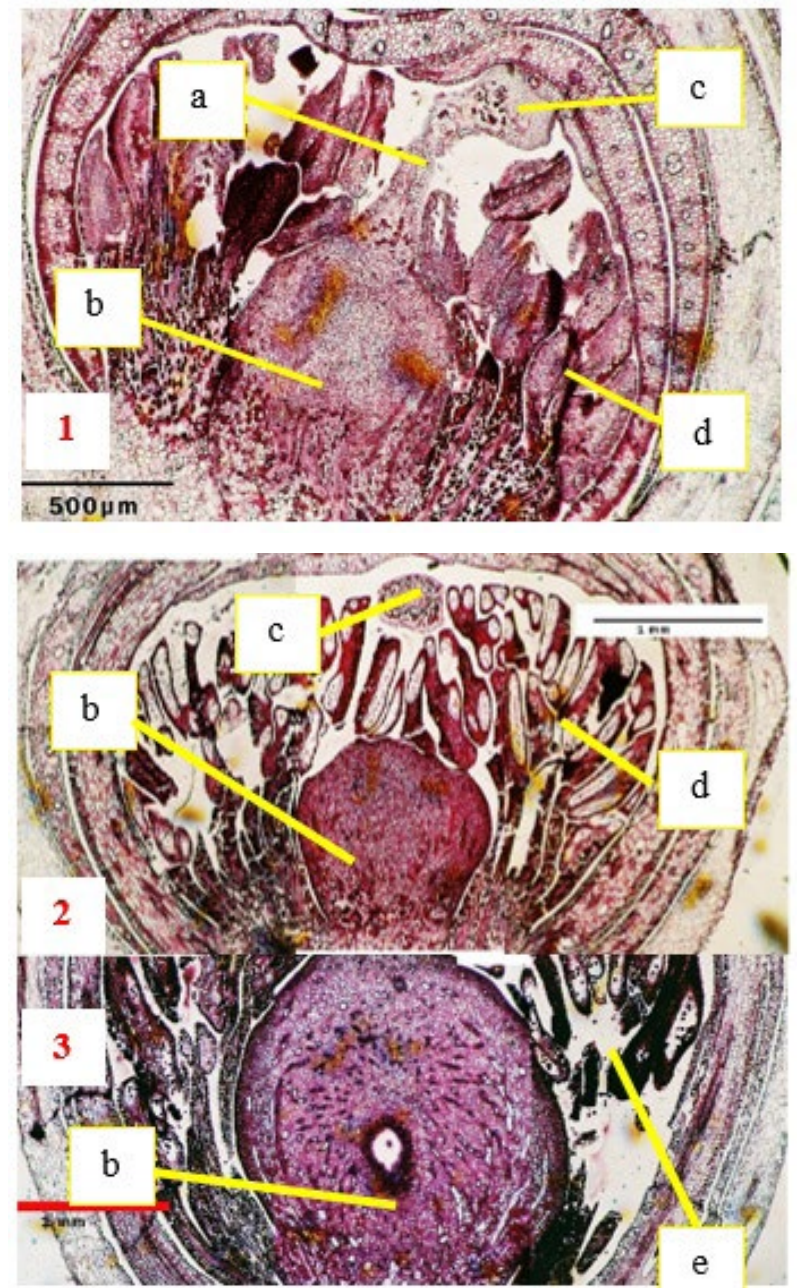

Gambar 6. Sayatan membujur (1) kuncup usia 7-8 HSI, (2) usia 15-16 HSI, dan (3) usia 21-22 HSI, semua gambar pada perbesaran 10x4 (a) tangkai putik. (b) bakal buah, (c) kepala putik, (d) kepala sari yang belum matang, (e) kepala sari yang sudah matang

Anthesis. Proses mekarnya bunga di tandai dengan membukanya 2 helai kelopak (Gambar 7.2). Kemudian diikuti dengan membukanya kelopak bunga yang lain sehingga kumpulan berkas benang sari berwarna kuning mulai terlihat (Gambar 7.3). Berkas benang sari tersusun mengelilingi putik, muncul diantara mahkota dengan putik, dan berpangkal di bawah putik.

Dalam satu tandan, bunga mekar tidak bersamaan. Namun tidak dilakukan pengamatan terhadap posisi bunga yang mekar terlebih dahulu. Terdapat kuncup yang tidak mekar sehingga kuncup tersebut rontok. Kuncup yang demikian umumnya berukuran lebih kecil dibanding dengan kuncup yang lain.

Lama bunga mekar selama 3 hari. Memasuki 4 HSA benang sari mulai jatuh, diikuti oleh patahnya tangkai putik sehingga bunga tanpa kepala putik lagi. Memasuki hari 6 HSA, 1-2 helai mahkota bunga mulai rontok. Pada 7 HSA bagian bunga tersisa hanya kelopak dan bakal buah. Selanjutnya bakal buah akan berubah warna menjadi kehijauan dan kelopak rontok pada 8-9 HSA. 
Bunga yang mekar banyak didatangi berbagai serangga seperti lebah, kumbang, kepik, dan semut. Warna bunga yang cerah dan aroma bunga mengundang serangga-serangga untuk mendatangi bunga. Diduga serangga tersebut berperan sebagai agen penyerbuk.

Bagian-Bagian Bunga. Bunga tersusun dalam tandan, setiap tandan memiliki 3 hingga 15 bunga. Masing-masing bunga pada umumnya memiliki 4 helai mahkota dan 4 helai kelopak berwarna putih, 1 putik dengan panjang $0.8-1 \mathrm{~cm}, 4$ berkas benang sari berwarna kuning. Namun ditemukan juga bunga dengan 5 helai kelopak, atau 3 helai kelopak atau 3 berkas benang sari. Diameter bunga berada dalam kisaran 1.90-3.08 cm. Kelopak dan mahkota umumnya tersusun radial, namun ditemukan kelopak dan mahkota yang tersusun sejajar, namun tidak terdokumentasi.

Terdapat perbedaan warna bakal buah yang dijumpai dalam pengamatan. Terdapat bakal buah dengan warna merah muda dan berwarna putih (Gambar 8). Keduanya dalam dua pohon yang berbeda, pohon pertama berwarna putih kekuningan sedangkan pohon kedua memiliki warna bakal buah merah cerah. Tidak ada perbedaan lain yang ditemukan pada bagian-bagian lain selain warna pada bakal buah tersebut.

Absisi Bunga. Tidak semua kuncup dewasa mengalami anthesis, demikian pula dengan buah, tidak semua buah muda tumbuh menjadi dewasa dan matang. Pengamatan di lapangan menunjukkan terdapat kerontokan di tingkat kuncup, bunga, dan buah usia muda.

Berdasarkan grafik kerontokan kuncup (Gambar 9) diketahui kerontokan kuncup mencapai puncaknya pada 24 HSI, yaitu sebesar $48.52 \%$ pada kuncup P1 dan $44.84 \%$ pada kuncup P2. Sedangkan pada bunga, tingkat kerontokan mencapai $61.5 \%$ pada $\mathrm{P} 1$ dan $64.5 \%$ pada P2.
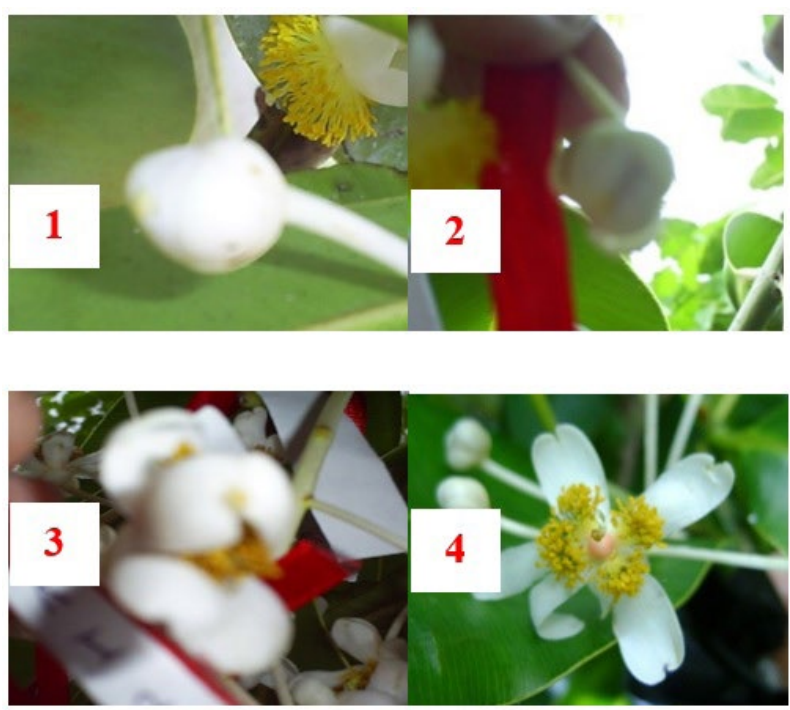

Gambar 7. Tahapan anthesis bunga, (1) kuncup dewasa, (2) kelopak mulai membuka, (3) sejumlah mahkota mulai membuka dan benang sari mulai terlihat, (4) bunga mekar
Perkembangan Buah. Berdasarkan grafik diameter buah (Gambar 10), kurva rata-rata diameter transversal dan longitudinal baik pada pohon $\mathrm{P} 1$ dan $\mathrm{P} 2$ berbentuk sigmoid. Pertambahan diameter longitudinal dan transversal tercepat terjadi pada minggu pertama hingga minggu ke-8 setelah anthesis (MSA). Memasuki 9 MSA pertambahan volume buah cenderung stabil. Baik diameter longitudinal maupun diameter transversal buah bertambah hanya sedikit.

Terjadi perubahan warna kulit buah dari hijau cerah menjadi hijau daun (Gambar 11). Tangkai buah yang semula berwarna putih juga berubah warna menjadi hijau cerah dan mengeras. Kulit buah mulai timbul bercak-bercak coklat pada usia 5 MSA, perlahan bercak-bercak coklat tersebut semakin lama semakin mendominasi kulit buah (Gambar 12). Buah matang pada 9 MSA. Kulit buah akan mudah terkelupas ketika buah matang dan tua yaitu pada usia 10-11 MSA, sehingga bagian endokarp terlihat. Banyak ditemukan buah matang yang telah jatuh dalam kondisi hanya endokarp dan biji yang tersisa.

Terjadi perubahan ukuran biji dan perikarp pada perkembangan buah berdasarkan sayatan membujur buah. Pada buah muda, ukuran biji masih kecil, endokarp masih belum terlihat jelas (Gambar 13.1). Endokarp mulai terbentuk pada usia buah memasuki 5 MSA seiring semakin tebalnya biji (Gambar 13.2). Ketebalan endokarp bertambah pada 7 MSA (Gambar 13.3). Sebaliknya, mesokarp ketebalannya menyempit seiring membesarnya ukuran biji dan menebalnya lapisan endokarp. Perikarp buah memiliki saluran kelenjar (secretory duct) yang berbentuk saluran kanal. Saluran tersebut tersebar di mesokarp buah. Setiap buah hanya memiliki satu biji.

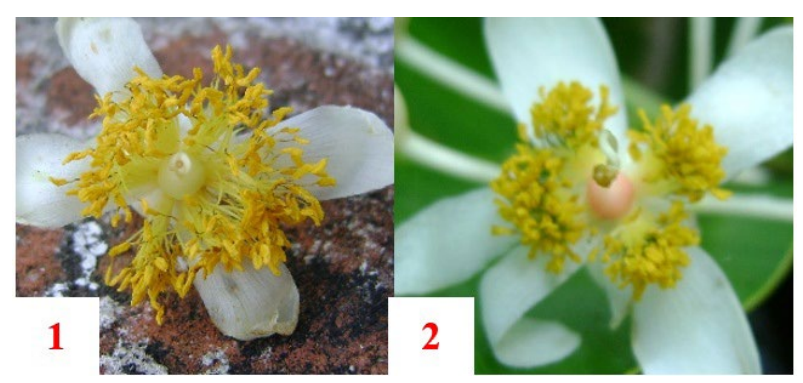

Gambar 8. Dua warna pada bakal buah, (1) putih kekuningan pada pohon pertama, (2) merah jambu pada pohon kedua

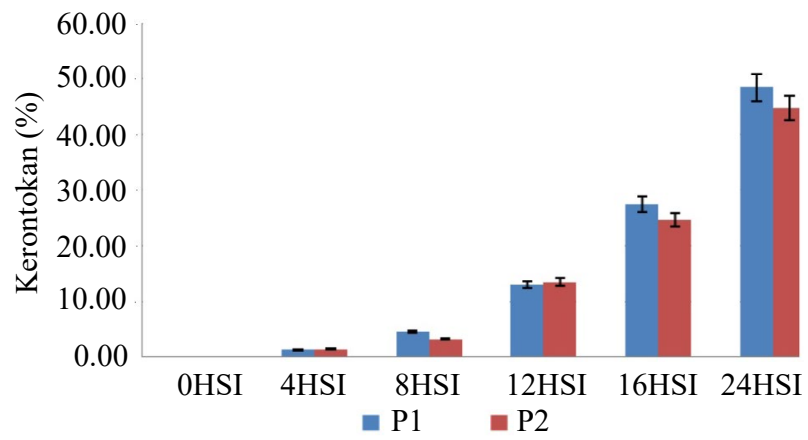

Gambar 9. Persentase kerontokan kuncup 
Kerontokan Buah. Berdasarkan persentase kerontokan buah (Tabel 1) diketahui bahwa pada buah P2 kerontokan terbesar terjadi pada 2 MSA
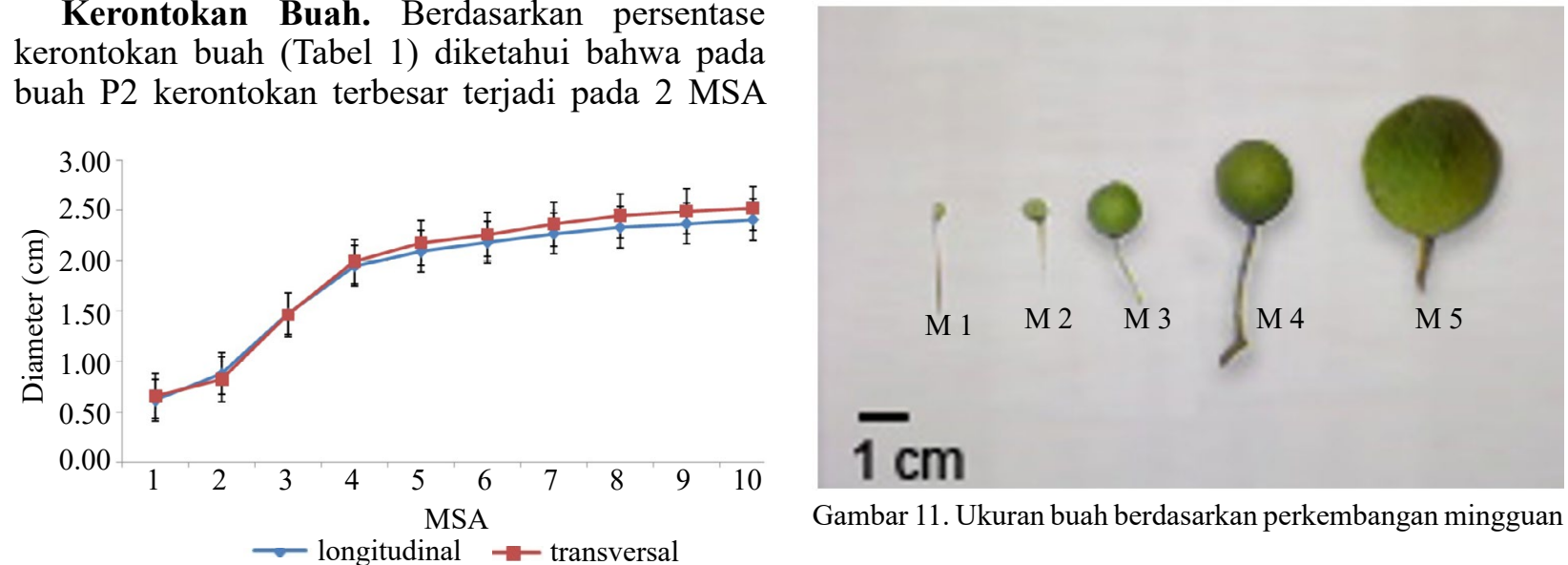

Gambar 11. Ukuran buah berdasarkan perkembangan mingguan
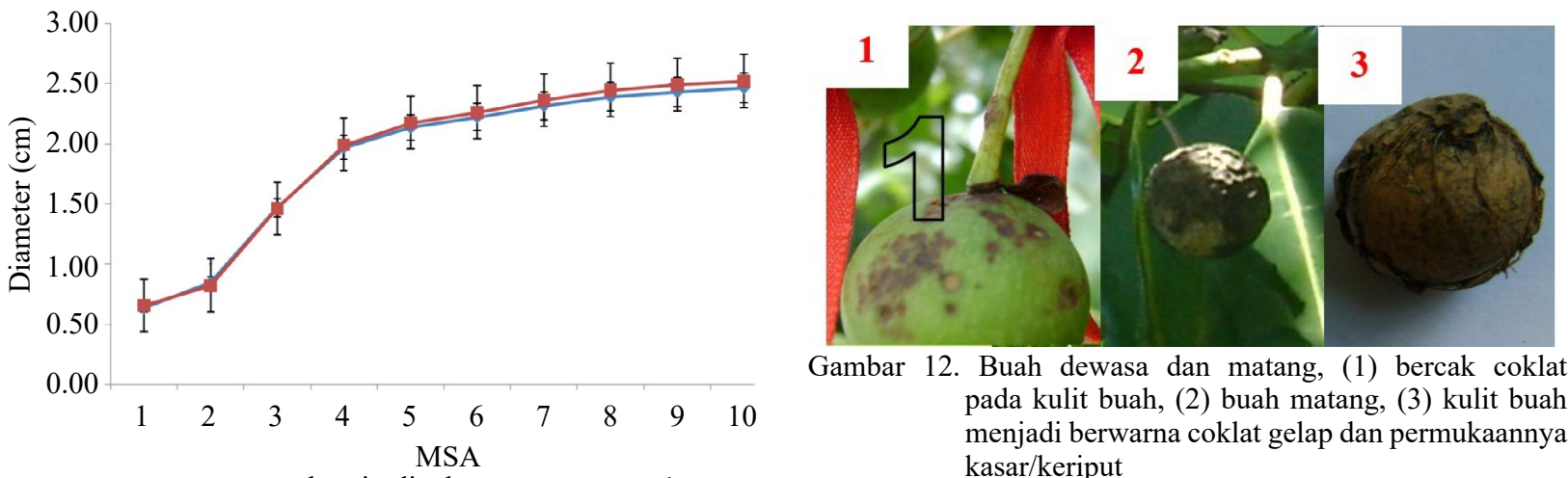

Gambar 12. Buah dewasa dan matang, (1) bercak coklat pada kulit buah, (2) buah matang, (3) kulit buah menjadi berwarna coklat gelap dan permukaannya

$\longrightarrow$ longitudinal $\rightarrow-$ transversal kasar/keriput

Gambar 10. Rata-rata diameter buah (1) P1 dan (2) P2
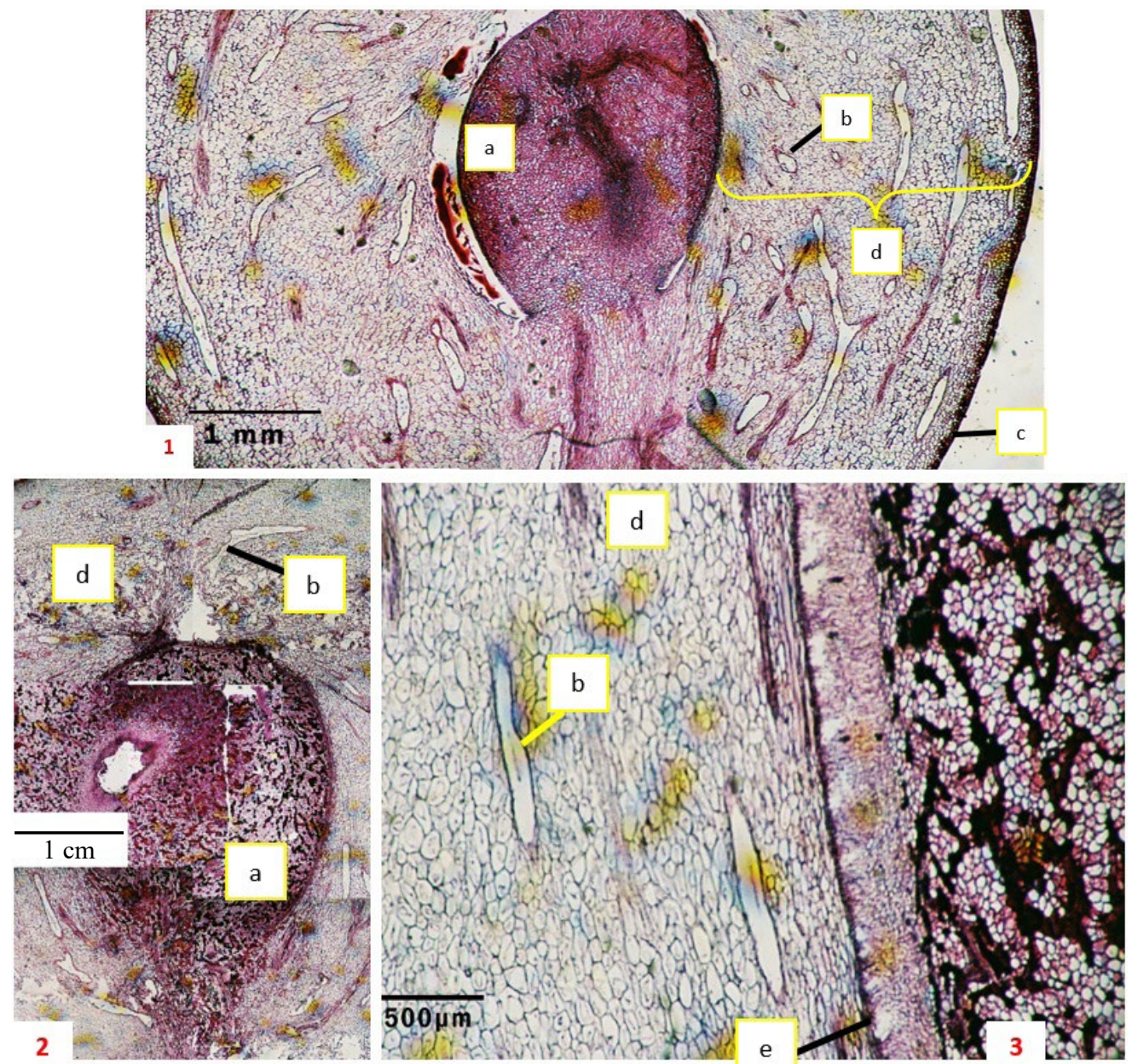

Gambar 13. Sayatan membujur buah, (1) usia muda (2 MSA) perbesaran 10x4, (2) usia dewasa (5 MSA) perbesaran 10x4, (3) usia 7 MSA perbesaran 10x10. Keterangan: (a) biji, (b) saluran kelenjar, (c) eksokarp, (d) mesokarp, (e) endokarp 
yaitu sebesar 18\%. Sedangkan pada P1 kerontokan terbesar terjadi pada 4 MSA yaitu sebesar $8 \%$. Secara umum P2 memiliki persentase kerontokan lebih besar dibanding P1. Kerontokan jarang terjadi pada 5 MSA hingga masa panen.

Dengan demikian, jika diamati daritahappembungaan hingga ke tahap pematangan buah pada C. inophyllum terdapat tiga titik absisi bunga dan buah. Pertama pada waktu kuncup bunga gagal anthesis, kedua pada bunga yang gagal menjadi buah. Ketiga, pada usia buah muda (2-4 MSA).

Bobot Buah. Rata-rata bobot basah buah P2 lebih besar dibandingkan dengan P1. Rata-rata bobot basah buah P2 sebesar 13.03 gr sedangkan pada P1 sebesar 12.46 gr. Berdasarkan grafik hubungan diameter dengan bobot basah buah (Gambar 14) didapat nilai koefisien korelasi (r) yang rendah yaitu 0.009 sehingga menunjukkan hubungan yang rendah antara bobot basah buah dengan volume buah. Sedangkan nilai $\mathrm{P}=0.672$. Lebih besar dari $5 \%$ menandakan pertambahan volume baik diameter polar maupun equatorial tidak dapat menduga bobot basah yang dihasilkan.

Kadar Lemak Biji. Biji dari buah yang sudah matang diambil untuk dilakukan pengujian kadar lemak. Hasil pengujian didapatkan biji dari pohon kedua memiliki kadar lemak tertinggi dengan nilai rata-rata sebesar $51.79 \%$. sedangkan biji dari pohon pertama memiliki nilai rata-rata sebesar $42.57 \%$ (Tabel 2).

\section{PEMBAHASAN}

Perkembangan Bunga. Berdasarkan grafik pertumbuhan panjang tunas, kurva pertumbuhan berbentuk sigmoid, artinya pertumbuhan (panjang)

\begin{tabular}{ccc}
\multicolumn{3}{l}{ Tabel 1. Persentase kerontokan buah } \\
\hline Umur (MSA) & Persentase & Buah rontok \\
\hline $0-1$ & 2 & 0 \\
2 & 0 & 18 \\
3 & 3 & 2 \\
4 & 8 & 10 \\
\hline
\end{tabular}

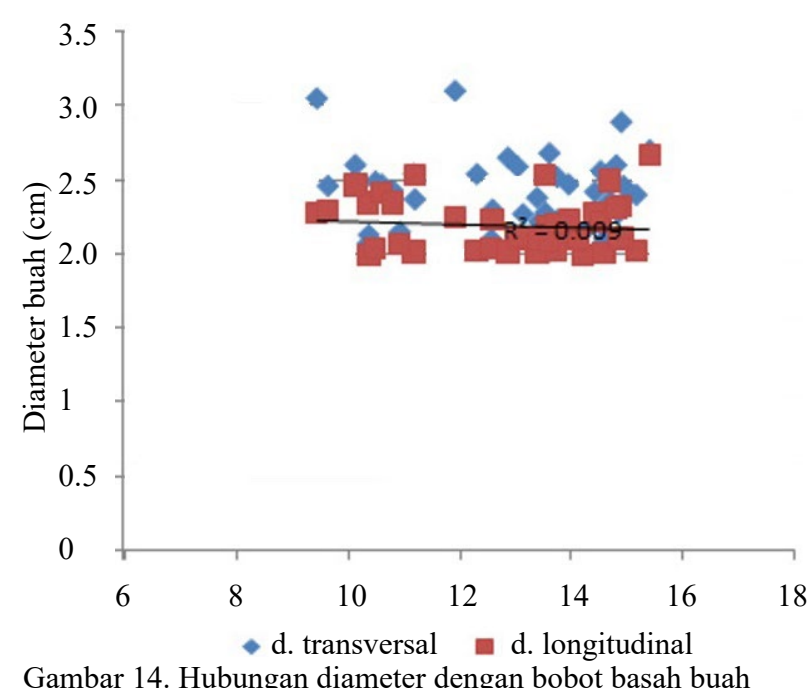

Tabel 2. Kadar lemak pada biji

\begin{tabular}{cc}
\hline Pohon & Kadar lemak \\
\hline P1 & $42.57^{\mathrm{b}}$ \\
P2 & $51.79^{\mathrm{a}}$ \\
\hline
\end{tabular}

dimulai dari bawah kemudian meningkat dan mencapai puncak setelah itu stabil. Pertumbuhan tunas bunga dipengaruhi beberapa faktor diantaranya suhu (Lyndon 1978; Catley dan Brooking 1996) maupun nutrisi hara (Fayaz et al. 2016). Gambar sayatan membujur kuncup menunjukkan tahapan perkembangan bagian dalam bunga. Pada penelitian ini tidak didapatkan gambaran sayatan membujur pada kuncup usia 1-3 HSI, sehingga tidak diketahui peristiwa pada usia tersebut. Usia 7-8 HSI kuncup telah memiliki bagian-bagian bunga, namun tak dapat diketahui proses-proses pembentukan bagian bunga tersebut. Menurut Banno et al. (1986), perkembangan histologis kuncup bunga pada buah pear diawali dengan tahap tak terdeferensiasi, berlanjut ke tahap pembentukan kelopak dan pusat bunga, kemudian berlanjut pada pembentukan stamen hingga akhirnya bagian-bagian bunga lengkap.

Berdasarkan jumlah dan tata letak bunga, $C$. inophyllum memiliki arsitektur bunga majemuk tak terbatas. Menurut Tjitrosoepomo (2001) bunga majemuk dikenali dengan adanya ibu tangkai bunga dan anak tangkai bunga, sedangkan bunga majemuk terbatas maksudnya ibu tangkai dapat tumbuh terus dengan cabang yang dapat bercabang lagi, kuncup yang berada pada ujung ibu tangkai merupakan kuncup termuda. Bunga $C$. inophyllum juga tersusun secara tandan karena memiliki tangkai yang jelas dan duduk di ibu tangkai. Masing-masing tangkai mendukung satu bunga.

Bunga dengan bagian-bagian bunga yang lengkap bertahan hingga 3 hari setelah anthesis, karena memasuki 4 HSI benang sari mulai rontok. Dapat dikatakan bahwa periode penyerbukan efektifnya (PEE) hanya 3 hari. Bunga dengan PEE yang relatif singkat juga ditemukan pada durian, namun telah diketahui bahwa kepala putik pada bunga durian telah memiliki kemampuan menerima serbuk sari beberapa jam sebelum anthesis (Honsho et al. 2007). Respon lingkungan seperti pencahayaan, kelembaban relatif atau suhu dapat mempengaruhi waktu dimulainya bunga anthesis (Reid 2005).

Berdasarkan pengamatan morfologi ketika anthesis, bunga $C$. inophyllum memiliki putik dan benang sari dalam satu bunga (biseksual), 4 helai mahkota, 4 helai kelopak, satu putik, dan empat berkas benang sari berwarna kuning. Hal yang sama diungkapkan oleh Steenis (2005) bahwa bunga $C$. inophyllum berkelamin ganda dan memiliki 4 helai mahkota dan 4 helai kelopak, serta benang sari berwarna kuning yang tersusun memusat.

Little dan Skolmen (2003) menambahkan bahwa panjang setiap helai mahkota 6-10 $\mathrm{mm}$ dan bunga $C$. 
inophyllum tersusun dalam tandan yang terdiri dari 4-15 bunga (Little dan Skolmen 2003; Steenis 2005), namun dalam penelitian ini paling sedikit ditemukan 3 bunga dalam satu tandan. Ditemukan juga dalam penelitian ini bunga dengan 5 helai kelopak atau 3 helai kelopak, atau bunga dengan 3 berkas benang sari.

Informasi lainnya dijelaskan dalam Steenis (2005) bahwa bunga $C$. inophyllum memiliki bau yang enak dan kepala putik berbentuk perisai dengan tangkai yang membengkok. Benang sari dengan filament berwarna cerah tersusun memusat, serta putik yang berwarna kemerahan, mengandung satu ovul didalamnya (Little dan Skolmen 2003).

Terhadap perbedaan warna pada bakal buah, Orwa et al. (2009) menjelaskan bahwa pada umumnya warna bakal buah adalah merah cerah, bunga $C$. inophyllum tergolong biseksual, namun terkadang berfungsi uniseksual. Hanya bunga hermaprodit yang memiliki bakal buah, yaitu berwarna merah muda cerah dan terlihat jelas ketika keseluruhan mahkota telah jatuh.

Absisi Bunga. Pada penelitian ini kerontokan bunga dimulai ketika masih dalam keadaan kuncup dengan titik persentase terbesar 3 hari menjelang anthesis (24 HSI), kemudian gelombang selanjutnya ketika bunga yang mekar namun gagal menjadi buah. Terdapat beberapa faktor yang mempengaruhi kerontokan bunga. Ristevski dan Kolekcevski (1995) melaporkan bahwa terdapat beberapa faktor yang menyebabkan kerontokan bunga yaitu: temperatur panas, varietas, altitude, dan kondisi meteorologis sebelumnya (kasus pada tanaman almond). Kurniawati dan Hamim (2009) juga menjelaskan bahwa factor endogen khususnya kandungan hormon auksin dan gibberellin merupakan faktor penting yang menentukan kerontokan bunga dan buah. Secara internal, kuncup atau bunga yang jatuh disebabkan oleh terhentinya suatu tahap tertentu seperti putik yang berhenti berkembang atau ovul yang tidak fungsional (Harold 1935).

Perkembangan Buah. Berdasarkan kurva pertumbuhan buah didapatkan bentuk kurva yang sigmoid dimana terdapat fase kenaikan signifikan kemudian pada titik tertentu terjadi kestabilan. Minggu ke-1 hingga minggu ke- 8 setelah anthesis (MSA) pertambahan diameter buah sangat tinggi. Hal ini karena buah mengalami pembelahan sel dan perbesaran sel dalam kurun waktu tersebut. Selanjutnya laju pertumbuhan akan turun. Tukey (1939) menyebutkan bahwa terdapat tiga karakteristik periode pertumbuhan buah. Tahap pertama dimana pertambahan perbesaran buah dengan cepat terjadi pasca anthesis bunga. Tahap kedua, merupakan periode pertengahan dimana buah mengalami penurunan dalam pertumbuhan. Pada tahap ketiga buah memasuki periode pematangan.

Kutchera (2000) menjelaskan bahwa terdapat tiga tahap perkembangan pada buah yaitu: Produksi sel-sel baru pada jaringan meristematik atau biasa disebut pembelahan sel, Perbesaran sel melalui vakuolaisasi dan penyerapan air, dan pematangan sel pasca pembesaran dengan pengerasan dinding sel dan bersifat final. Pembelahan sel secara cepat terjadi pada jaringan meristematik, sifat pertumbuhannya irreversible, dan melalui mekanisme mitosis (Kutschera 2000).

Memasuki usia pematangan terlihat penambahan diameter buah tidak terlalu signifikan. Hal ini karena tahap pematangan ini dikontrol secara metabolik (Kutschera 2000), sehingga aktivitas pembelahan dan perbesaran sel berkurang. Selain itu, pada usia pematangan ketebalan perikarp berkurang dan tebal biji meningkat. Pada buah yang tua, kadar air lebih rendah dibandingkan dengan buah muda, sehingga sel-sel penyusun jaringan perikarp mengkerut dan akibatnya kulit buah menjadi tipis (Dorly 2009). Hal ini menyebabkan buah yang sudah matang berangsurangsur berwarna coklat dan kulit buah mengering (kecoklatan) karena kehilangan kadar air .

Kerontokan Buah. Kerontokan buah terjadi dari 1 MSA hingga 4 MSA. Secara kuantitas, kerontokan buah terbesar terjadi pada 4 MSA pada P1, sedangkan kerontokan buah pada $\mathrm{P} 2$ terbesar terjadi pada 2 MSA. Beberapa tumbuhan memiliki variasi kerontokan buah yang berbeda. Pada tanaman belimbing misalnya, kerontokan buah maksimum terjadi pada hari ke-4 setelah antesis dan terus berlanjut hingga berhenti setelah pada hari ke-26 setelah antesis (Kurniawati dan Hamim 2009). Terhadap buah yang rontok, Harold (1935) menjelaskan bahwa perbedaan antar buah yang jatuh dengan buah yang terus berkembang adalah adanya proses yang terhenti di satu hal dan proses yang berlanjut di satu hal lain. Perbedaan antara buah jatuh dengan yang tidak pada saat periode jatuh menunjukkan derajat perkembangan dan proses normal yang terhenti. Secara struktural tidak ditemukan perbedaan dan bukanlah yang menjadi alasan proses perkembangan itu terhenti. Pengamatan di lapang juga menunjukkan bahwa tidak ada perbedaan secara struktur antara buah yang jatuh dengan buah yang tetap tumbuh.

Ryugo (1988) menjelaskan bahwa terdapat tiga gelombang absisi bunga dan buah. Gelombang pertama terjadi ketika bunga sudah saatnya untuk mekar, namun faktor lingkungan seperti suhu yang kurang mendukung mampu menyebabkan absisi. Gelombang kedua terjadi ketika bunga tidak mengalami pembuahan setelah mekar. Kurang lebih sepuluh hari setelah itu terjadi gelombang yang ketiga 
dimana buah sudah seukuran biji kacang (pada buah pear).

Bobot Buah. Rata-rata bobot basah buah P2 lebih besar dibandingkan dengan P1. Hasil analisis regresi menunjukkan hubungan yang rendah antara bobot basah buah dengan diameter buah. Rendahnya nilai korelasi antara diameter dengan bobot buah dapat dijelaskan bahwa volume buah tidak selalu mewakili pertumbuhan sebab bisa saja bagian dalam buah terdapat celah-celah atau kulit buah yang mengalami penebalan tidak pada umumnya Ognjanov et al. (1995). Kesulitan dalam menentukan berat atau volume buah menyebabkan banyak kalangan hortikultura menggunakan perhitungan diameter polar atau equatorial untuk mengevaluasi percobaan dan efek lingkungan atau untuk memperkirakan tahap-tahap fisiologis buah saja (Ognjanov et al. 1995), maksudnya perhitungan diameter buah tidak dapat menduga hasil panen yang didapatkan.

Kanopi atas lebih banyak menghasilkan buah. Hal ini karena daun di posisi kanopi atas menerima lebih banyak cahaya matahari untuk fotosintesis. Menurut Ryugo (1988), pengaruh posisi dalam kanopi berhubungan dengan banyak tidaknya cahaya yang diterima oleh daun dan buah. Buah yang tumbuh dalam naungan biasanya lebih kecil dibanding buah yang tumbuh dengan paparan cahaya yang baik. Ukuran yang kecil tersebut mengindikasikan daun terdekat juga ternaungi sehingga pasokan hasil fotosintesis juga berkurang. Akan tetapi secara umum produksi buah dalam setiap musimnya tergantung pada jumlah tunas buah yang terdiferensiasi, jumlah bunga yang kemudian mekar dan anthesis dan bunga yang kemudian berkembang menjadi buah.

Uji Kadar Lemak. Prihandana dan Hendroko (2007) menyebutkan kadar lemak pada biji buah nyamplung berada dalam kisaran 41-73\%. Pada penelitian ini didapatkan nilai $42.57 \%$ dan $51.79 \%$. Kisaran tersebut melebihi kisaran tanaman jarak pagar (40-60\%), wijen (45-55\%), dan malapari (Pongamia pinnata; 27-39\%). Kisaran yang hampir sama dengan kemiri (57-69\%) dan kelapa sawit (45-70\%), namun masih di bawah kelapa (60-70\%) (Prihandana dan Hendroko 2007).

Azam (2005) memperkirakan, jika dibandingkan dengan jarak pagar (J. curcas) dengan luasan lahan yang sama (1 ha) nyamplung dapat menghasilkan 3744 1t/ha, sedangkan jarak pagar menghasilkan 2000 lt/ha. Kondisi tersebut berlaku jika jarak tanam per pohon nyamplung $5 \times 5$ meter dan $2 \times 2$ meter pada jarak pagar. Juga diasumsikan bahwa setiap pohon nyamplung menghasilkan $65 \%$ minyak lemak. Dengan demikian, tanaman ini cukup potensial untuk dijadikan sebagai sumber biodiesel.

\section{KESIMPULAN}

Perkembangan bunga nyamplung (Calophyllum inophyllum L.) dari tunas hingga menjadi kuncup dewasa memerlukan waktu 27 HSI. Bunga mekar selama 3 hari, kemudian pada 6 HSA beberapa bagian bunga telah gugur sehingga tersisa bakal buah saja. Bunga tersusun dalam tandan yang terdiri dari 8-15 bunga. Terdapat perbedaan warna bakal buah pada putik yaitu putih kekuningan (pada P1) dan merah jambu (pada P2). Total prosentase kerontokan kuncup tertinggi pada 24 HST yang mencapai $48.52 \%$, sedangkan pada bunga kerontokan mencapai $64.5 \%$.

Buah dari kecil hingga buah matang memerlukan waktu 10-11 MSA. Pertumbuhan buah memiliki pola sigmoid jika didasarkan pada diameter buah. Buah berwarna hijau muda, dan semakin dewasa warna buah semakin tua dan muncul bercak kecoklatan yang akan mendominasi warna buah matang.

Biji dari P2 memiliki kadar lemak 51.79\% sedangkan biji dari P1 memiliki kadar lemak $42.57 \%$. Tingginya kadar lemak yang dimiliki biji nyamplung menjadikan tanaman ini sangat potensial untuk dikembangkan sebagai sumber biodiesel.

\section{DAFTAR PUSTAKA}

Adinugraha HA, Mahfudz WM, Ekowati S, Huda. 2012. Pertumbuhan dan perkembangan tunas bibit nyamplung hasil pembiakan dengan teknik sambungan. Jurnal Pemuliaan Tanaman Hutan 6:89-100.

Azam MM, Waris A, Nahar NM. 2005. Prospects and potential of fatty acid methyl esters of some non-traditional seed oils for use as biodiesel in India. Biomass and Bioenergy 29:293-302.

Banno K, Hayashi S, Tanabe K. 1986. Morphological and histological studies on flower bud differentiation and development in Japanese pear (Pyrus serotina Rehd). $J$ Japan Soc Hort Sci 55:258-265.

Catley JL and Brooking IR. 1996. Temperature and light Influence growth and flower production in heliconia 'golden torch'. Hort Sci 31:213-217.

Danuwarsa. 2006. Analisis proksimat dan asam lemak pada komoditas kacang-kacangan. Buletin Teknik Pertanian 11:5-8.

Dorly. 2009. Studi Struktur Sekretori Getah Kuning dan Pengaruh Kalsium Terhadap Cemaran Getah Kuning Pada Buah Manggis (Garcinia mangostana L.) [Disertasi]. Bogor: Institut Pertanian Bogor.

Dweck AC, Meadows T. 2002. Tamanu (Calophyllum inophyllum) the African, Asian, Polynesian, and Pacific Panaceae. International Journal of Cosmetic Science 24:1-8.

Fayaz K, Singh D, Singh VK, Bashir D, Kuller LR. 2016. Effect of NPK on plant growth, flower quality and yield of gerbera (Gerbera jamesonii). Res Environ Life Sci 9:1361-1363.

Fiani A. 2015. Growth of six populations of Calophyllum inophyllum of Java land race at five years of age at the ex situ conservation plot in Cilacap, Central Java. Pros Sem Nas Masy Biodiv Indon 1:900-903. 
Friday JB, Okano D. 2006. Species profiles for Pacific Island. Traditional Tree Initiative Buletin:1-4

Hamim, Miftahudin. 2008. Tantangan dan kendala pengembangan komoditas penghasil bahan bakar nabati (biofuel): studi kasus di Bali dan Nusa Tenggara. In: Prosiding seminar nasional sains. Bogor: FMIPA-IPB p 1-6.

Harrold JT. 1935. Comparative study of the developing and aborting fruits of prunus persica. Botanical Gazette 96:505-520.

Heyne K. 1987. Tumbuhan Berguna di Indonesia. Badan Litbang Kehutanan, Departemen Kehutanan. Jakarta: Yayasan Sarana Warna Jaya.

Honsho C, Somsri S, Tetsumura T, Yamashita Y, Yonemori Y. 2007. Effective pollination period in durian (Durio zibethinus Murr.) and the factors regulating it. Scientia Horticulturae 111:193-196.

Johansen DA. 1940. Plant Microtechnique. New York: McGrawHill Book Company Inc.

Kurniawati B dan Hamim 2009. Physiological responses and fruit retention of carambola fruit (Averrhoa carambola L.) induced by 2,4-D and GA3. Hayati J Biosci 16:9-16.

Kutschera U. 2000. Cell expansion in plant development. R Bras Fisiol Veg 12:65-95.

Leksono B, Hendrati RL, Windyarini E, Hasnah T. 2014. Variation of biofuel potential of twelve Calophyllum inophyllum populations in Indonesia. Indonesian Journal of Forestry Research 1:127-138.

Little Jr E, Skolmen RG. 2003. Agriculture Handbook No 679. Hawai: College of Tropical Agriculture and Human Resource.

Lyndon RF. 1978. Rates of growth and primordial initiation during flower development in silene at different temperatures. Ann Bot 43:539-551.
Ognjanov V, Vujanić-Vargaa D, Mišić PD, Verešbaranji I, Macet K, Tešović Z, Krstić M, Petrović N. 1995. Anatomical and biochemical studies of fruit development in peach. Scientia Holticulturae 64:33-48.

Orwa C, Mutua A, Kindt R, Jamnadas R, Anthony S. 2009. Agroforestree Database: a tree reference and selection guide v4. Tersedia di: www.worldagroforestry.org/sites/ treedbs/treedatabases.asp [Data akses: 5 Desember 2009]

[P3HH] Pusat Penelitian dan Pengembangan Hasil Hutan. 2008. Nyamplung (Calophyllum inophyllum) Departemen Kehutanan RI.

Prihandana R, Hendroko R. 2007. Energi Hijau: Pilihan bijak menuju negeri energi mandiri. Jakarta: Penebar swadaya.

Putri AP and Gheewala SH. 2015. Renewability assessment of kamani (Calophyllum inophyllum) biodiesel in Indonesia. J Sustain En Environ 6:9-12.

Reid MS. 2005. Flower development: from bud to bloom. Acta Hort 669:105-109

Ristevski B, Kolekcevski P. 1995. Flower bud in Almond. CIHEAM-Options Mediterranenses 53:29-33.

Rahayu SS. 2009. Penelusuran senyawa sitotoksik pada kulit biji nyamplung (C. inophyllum) dan kemungkinan korelasinya sebagai anti kanker. Jurnal Kimia 3:101-108.

Ryugo. 1988. Fruit Culture: it's Science and Art. New York: John Wiley and Son.

Steenis CGGJ van. 2005. Flora untuk Sekolah di Indonesia. diterjemahkan oleh: Surjowinoto M. et al. Jakarta: Pradnya Paramita. Terjemahan dari: Flora.

Tjitrosoepomo G. 2001. Morfologi Tumbuhan. Yogyakarta: Gadjah Mada University Press.

Tukey HB, Young OJ. 1939. Histological study of the developing fruit of sourcherry. Botanical Gazzete 200:723-732. 